\title{
USING PLM TRAining AND CONSUlTing IN UNIVERSITY - ENTERPRISES PARTNERSHIP
}

\author{
COTET, C.E.; Popescu, D.; Guran, M.; Dragoi, G.; CARUTASU, \\ G. \& CARUTASU, N.L.
}

Abstract: Taking into account that the Romanian enterprises are still in the first stages of integrating the PLM approach, we started a partnership implying INPRO, a Romanian national research network with its traditional industrial partners as well as the PLM solutions providers on the Romanian market. The new product proposed by the national INPRO Research Network implying research centres and universities located in different Romanian geographical areas and the IBM/DASSAULT and UGS as PLM solutions providers is a package of services and training modules available on $C D$, on paper, and on Internet for open distance learning, based on a new Virtual Enterprise (VE) oriented curricula. In the training process we had included as a new multi site networking relationship between partners' on-line applications at the PLM modules training courses interconnecting the research and the industrial partners. UPB-PREMINV Research Centre as a member in this partnership also started a comparative performances analysis of those two PLM approaches considering the specific enterprises needs. Finally an appropriate and personalized solution should be available for every one of those industrial partners of the research network who expressed their interest in implementing PLM solutions.

Key words: PLM, SME, virtual training laboratory, outsourcing, partnership
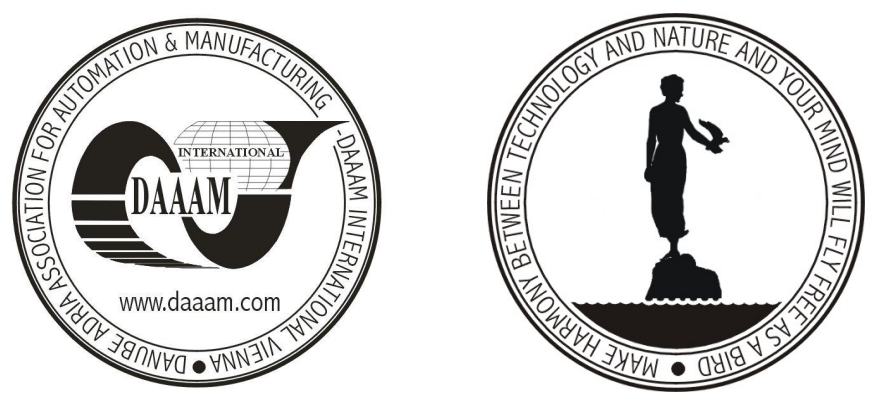

Authors' data: Dr. eng. Cotet, C[ostel] E[mil]*; Dr. Popescu, D[iana $]^{*}$; Dr. eng. Guran, M[arius]*; Dr. eng. Dragoi, G[eorge]*; PhD, Eng Carutasu, G[eorge]**; Ass. Prof. Carutasu, N[icoleta] L[uminita ${ }^{*}$, * University POLITEHNICA of Bucharest, Splaiul Independentei, 313, sector 6, Bucharest, Romania, ** Romanian-American University, $5^{\text {th }}$ Croitoru V. St., $3^{\text {rd }}$ Building, 39 ${ }^{\text {th }}$ Apartment, $5^{\text {th }}$ District, Bucharest, Romania, costel@mix.mmi.pub.ro,_diana@mix.mmi.pub.ro,_gdragoi@mix.mmi.pub.ro, mguran@mix.mmi.pub.ro,georgecarutasu@yahoo.com, nicoleta@mix.mmi.pub.ro

This Publication has to be referred as: Cotet, C.E.; Popescu, D.; Guran, M.; Dragoi, G.; Carutasu, G. \& Carutasu, N.L.. (2007). Using PLM Training and Consulting in University Enterprises Partnership, Chapter 13 in DAAAM International Scientific Book 2007, B. Katalinic (Ed.), Published by DAAAM International, ISBN 3-901509-60-7, ISSN 17269687, Vienna, Austria

DOI: $10.2507 /$ daaam.scibook.2007.13 